\title{
Validity and Reliability Study of James Supportive Care Screening for Cancer Patients
}

\author{
Hacer DEMIRKOL, Olcay ÇAM \\ Department of Mental Health and Diseases Nursing, Ege University Faculty of Nursing, Izmir-Turkey
}

\begin{abstract}
OBJECTIVE
The present study examined the validity and reliability of the James Supportive Care Screening (SCS), a tool to measure the distress of those diagnosed with cancer, for Turkish patients.

\section{METHODS}

After necessary approval was obtained from the oncology hospital, research was conducted with 280 chemotherapy outpatients. Content validity, construct validity, and criterion-related validity tests were used to evaluate validity of SCS use in Turkey, while internal consistency and test-retest reliability were measured to determine reliability.
\end{abstract}

\section{RESULTS}

Content validity index value based on ratings of experts on all items of SCS found on above 0.80 . The Turkish version of the scale has 48 items based on 6 factors, and is similar to the original SCS measure. Confirmatory factor analysis. Cronbach's alpha value of scale was 0.918 and unchangeability against time was proven.

\section{CONCLUSION}

James Supportive Care Screening is a valid and reliable measurement tool for screening Turkish cancer patients.

Keywords: Cancer; distress; validity; reliability.

Copyright $\odot$ 2016, Turkish Society for Radiation Oncology

\section{Introduction}

Cancer is an important chronical disease, mortality rate of which is high, that brings important life changes with it.[1-3] Even though many diagnostic and treatment methods have been recently developed, individuals are confronted with many problems and distress related with them as physically, psychologically, and in social lives. [4-7]

In literature, distress is defined as undesired emotional experiences occurring multidimensional in psyhological (cognitive, behavioral, emotional), social, and spiritual ground that have a negative impact on a patient's coping with the disease.[8] As some researches made to specify the distress experienced my some individuals with diagnosis of cancer are analyzed, it was stated that $51 \%$ of 168 individuals diagnosed with cancer were experiencing distress. [9] In a research made by Liao and his friends (2015) over 97 individuals diagnosed with cancer, it was stated that all of the patients experienced distress at intermediate level and that the level of distress had increased dur- 
ing the treatment period.[10] Similarly, in a research made with 500 individuals diagnosed with cancer, it was stated that $50.8 \%$ of them experienced distress. [11] As seen in different researches conducted, distress, which is a multidimensional symptom, is seen in individuals diagnosed with cancer at varying rates. [9-13] Furthermore, there are many researches made proving that there are problems that exist causing individuals to experience distress in physical, social, and spiritual areas of life.[14-22]

Thus, the problems experienced by individuals diagnosed with cancer and distress that occur as a result of these problems should be handled together. As each area of life interacts with one another, problems get more complicated while correlation between life quality and disease is being negatively influenced. $[23,24]$ In our country due to reasons like patient density, lack of personal, and not having a standard measurement device for specifying distress in a wide perspective, problems and distress experienced by individuals being diagnosed with cancer can be missed by health professionals while lack of supportive treatment can be seen. One of the most important steps that can be taken to eliminate this deficiency, is to use standard measurement devices specifying distress experienced by the individuals who are diagnosed with cancer in a wide perspective. [6,8,25]

Usage of standard measurement devices will enable for the determination of distress experienced by individuals who are diagnosed with cancer while making it possible for supportive treatment to be provided at an early stage. Supportive care treatment is a special care modeling while family and the individual are taken to the center for all factors, including individual values, beliefs, and cultural issues, to be managed in an effective way.[8] Providing supportive care treatment to the patients, after being diagnosed with cancer, will enable patient's harmonization with the disease and their life quality to be improved.[26,27]

In this research it is aimed for the adjustment of SCS, that measures distress and the problems experienced by individuals in all areas of life in an extensive way, to the Turkish culture and to ensure its validity and reliability. By the usage of a standard measurement device for measuring distress experienced by individuals diagnosed with cancer in our country in clinical environment, it is thought that the problems experienced by individuals won't be missed and that supportive care treatment shall be provided at an early stage.

\section{Materials and Methods}

\section{Space and Sampling}

For a scale to be considered as a standard measurement tool outside of the country as well, it is required for a validity and reliability study to be conducted including psycholinguistic (language application) and psychometric (validity-reliability) processing.[28,29] Following the approvals received from scale owner, ethical council of the university, and the hospital where the research will be conducted, individuals applying to get chemotherapy treatment at Tülay Aktaş Oncology Hospital as part of Ege University Medical Faculty Hospital, make up the research population. Number of items of SCS are 48. In literature, it is stated that in scale validity and reliability studies, the number of sampling should be at least five times the number of items related with the scale.[30] By taking this information into consideration, the sampling of the research was specified as 280 volunteering individuals composed of outpatients applying to get chemotherapy treatment being over 18 years of ago and not having any physical or mental diseases that could avoid them from understanding or replying questions asked to them. The SCS was read to 280 individuals being diagnosed of cancer, by the researcher himself and the answers given by the individuals have been marked by the researcher. Filling of SCS was completed in 10 minutes on the average.

\section{Data Collection Tools}

Introductory Information Form: Introductory information form which is prepared by the researchers by analyzing the literature, is a form composed of 11 questions in total questioning particulars like age, gender, marital status, educational status, occupation, income level, existence of any physical or mental diseases other than cancer, the type of cancer disease, the stage of cancer disease, and the time of being diagnosed with cancer.

James Supportive Care Screening (SCS): The SCS, was developed by Wells-Di Gregorio and his friends (2013) for measuring the distress experienced by individuals being diagnosed with cancer and to specify the areas where they need support. It is composed of 48 items and six subscales in total. Subscales of the scale are composed of emotional concerns (14), spiritual/religious concerns (4), health care concerns (4), social/ practical problems (6), cognitive concerns (3), and physical symptoms (17) questions. Scaling questions are answered by using the options of: None (0), mild (1), moderate (2), and severe (3). A total score could be 
obtained or evaluations could be made per each question. As the total score increases, the level of distress experienced increases.[31]

EORTC QLQ C-30 Life Quality Scale (European Organisation for Research and Treatment of Cancer Quality of Life): The scale which was developed by European Organisation for Research and Treatment of Cancer, is composed of three sections as functional scale, global health status scale, and symptom scale and it contains 30 questions in total. Total score for scaling could be evaluated or functional scores could be calculated separately as being part of the scaling. The high score which is obtained from functional scales show healthy functional level and high life standard, the high score obtained from global health status scale shows high life quality, and the high score obtained from symptom scale shows that the symptoms are being experienced heavily and that the life quality is low. Turkish validity and reliability of the scale was conducted by Güzelant and his friends (2004) and Cronbach alpha coefficient was found to be $\geq 0.70$. [32,33]

\section{Validity Studies}

Linguistic Validity and Content Validity: First of all, original scale has been translated from English to Turkish by five experts (one psychologist, one psychological consultancy specialist, two experts specialized in the nursing related with mental health and diseases, one teacher who is graduated from English Language and Literature Division) by conducting a group translation. The Turkish form which was obtained after the translation was further translated from Turkish to English by two translators, with English being their mother tongue, who have been living in Turkey for many years as a common study conducted by them. The expressions in this translation and the expressions used in original scaling were compared and the required adjustments were done in line with the recommendations made by the translators. In order to ensure content validity, the latest version of scale has been presented to ten experts who knew the technics and methods used in preparing scale questions well. In the evaluation of opinions of experts, Davis technic has been used.[34]

Construct Validity: As relating with the construct validity of the scale, Confirmatory Factor Analysis (CFA), being recommended for scale adjustment works, has been used.[35,36]

Criterion-Related Validity: The correlation between the subscales of SCS, namely emotional concerns, cognitive concerns, and physical symptoms with emotional functional score, cognitive functioning score, and total score of symptom scale of EORTC QLQ C-30 Life Quality Scale has been controlled by calculating pearson moment correlation coefficient.

\section{Reliability Studies}

Internal Consistency Analysis: In order to analyze the internal consistency of SCS, Cronbach alpha coefficient of the scale and its subscales and item-total correlation values of the item have been calculated.

Unchangeability against Time (Test-Retest Method): The scale has been reapplied to 30 people after two weeks' time. Analysis was made by calculating the correlation coefficients in the first and final applications.

For the evaluation of data, SPSS and LISREL package programs have been used.

\section{Findings}

\section{Findings Relating to Introductory Information}

It was determined that among those participating in the research, $65.7 \%(n=184)$ were women, $79.6 \%(n=223)$ were married, $40.4 \%(n=113)$ were junior high school or high school graduates, $44.3 \%(\mathrm{n}=124)$ were retired, and $50.4 \%(\mathrm{n}=141)$ had incomes which were in balance with their expenses. The average age of the individuals was specified as $51.92 \pm 12.225$ years.

It was determined that $38.2 \%(n=107)$ of the participants were diagnosed with breast cancer and that among 219 individuals, whose phase was specified (cancer phase of 61 individuals was not determined as it could not be found out yet or due to the missing parts existing in the registry system), $37.1 \%(\mathrm{n}=104)$ were in the 4 th phase and that $31.4 \%$ also had physical illness accompanying cancer and that $3.6 \%(\mathrm{n}=10)$ were also diagnosed with mental illness in addition to cancer. Furthermore, it was determined that the individuals participating in the research were diagnosed with cancer $44.9 \pm 4.17$ months ago.

\section{Findings Relating with Validity Studies}

As the opinions of experts were evaluated by using Davis technic, Content Validity Index (CVI) of all items were found to be over 0.80 . In literature, it is stated that as relating with content validity, CVI value of each item should be minimum 0.80.[34] Later on, as regards to face validity, the scale was applied to 15 individuals who were diagnosed with cancer but were not included in the sampling. It was requested from 15 individuals having applied for face validity, to make comments about legibility, understandability, and sorting of scale items. [30] Even though CVI ratio came out to be high- 
Table 1 Standard fit indices of confirmatory factor analysis compare with results of research

\begin{tabular}{lcccc} 
Index & Perfect fit criteria & Good fit criteria & Research findings & Result \\
\hline$X^{2} / \mathrm{SD}$ & $0-3$ & $3-5$ & 2.073 & Perfect fit index \\
RMSEA & $0.00 \leq \mathrm{RMSEA} \leq 0.05$ & $0.05 \leq \mathrm{RMSEA} \leq 0.10$ & 0.062 & Good fit index \\
CFI & $0.95 \leq \mathrm{CFI} \leq 1.00$ & $0.90 \leq \mathrm{CFI} \leq 0.95$ & 0.91 & Good fit index \\
NNFI & $0.95 \leq \mathrm{NNFI}(\mathrm{TLI}) \leq 1.00$ & $0.90 \leq \mathrm{NNFI}(\mathrm{TLI}) \leq 0.95$ & 0.91 & Good fit index \\
NFI & $0.95 \leq \mathrm{NFI} \leq 1.00$ & $0.90 \leq \mathrm{NFI} \leq 0.95$ & 0.90 & Good fit index \\
SRMR & $0.00 \leq \mathrm{SRMR} \leq .05$ & $0.05 \leq \mathrm{SRMR} \leq 0.08$ & 0.07 & Good fit index \\
GFI & $0.95 \leq \mathrm{GFI} \leq 1.00$ & $0.90 \leq \mathrm{GFI} \leq 0.95$ & 0.90 & Good fit index \\
AGFI & $0.90 \leq \mathrm{AGFI} \leq 1.00$ & $0.85 \leq \mathrm{AGFI} \leq 0.90$ & 0.92 & Good fit index \\
\hline
\end{tabular}

RMSEA: Root mean square error of approximation; CFI: Comparative fit index; NNFI: Non-normed fit index; NFI: Normed fit index; SRMR: Standardised root mean square residual; GFI: Goodness of fit index; AGFI: Adjusted goodness of fit index.

er than 0.80 for all the articles in the scale, in line with the recommendations made by the experts and 15 individuals, minor changes have been made and the scale was given its final form.

Before applying CFA method, in order to determine the sufficiency of sampling, Kaiser-Meyer-Olkin Measure of Sampling Adequacy (KMO) and Bartlett Test of Sphericity tests have been applied and the outcomes were found to be meaningful $(\mathrm{KMO}=0.845$, $\left.\mathrm{X}^{2}=5043.087, \mathrm{p} \leq 0.000\right)$. In addition, Power analysis was conducted as Post Hoc and it was seen that the sampling was powerful with a rate of $81.3 \%$.

Following CFA conducted in order to make the evaluation of construct validity, fit indices which are shown in Table 1 and the model relating with Turkish form of the scale illustrated in Figure 1 have been found out. The model which was specified in Turkish, fitted to the original model and it could measure the structure it was aimed to measure with validity in six dimensions as was determined (Table 1 and Figure 1).

A meaningful relationship was found between the subscales of emotional concerns of SCS and the emotional functioning score of EORTC QLQ C-30 Life Quality Scale in the negative correlation and again a meaningful relationship was found between the subscales of cognitive concerns of SCS and the cognitive functional score of EORTC QLQ C-30 Life Quality Scale, in the negative correlation (Table 2). Between the subscales of SCS relating with physical symptoms and the symptom scale of EORTC QLQ C-30 Life Quality Scale, a meaningful relationship was found in the positive correlation (Table 2).

As the total score of SCS was analyzed per gender, it was determined that distress score average was $29.58 \pm 19.594$ for women and that it was $20.57 \pm 16.680$ for men.

\section{Findings Relating with Reliability Studies}

As Cronbach alpha coefficients of SCS and its subscales were calculated, it was determined that Cronbach alpha coefficient of subscales was above 0.50 and that Cronbach alpha coefficient of the scale was 0.918 (Table 3).

As item-total correlation coefficient of SCS, being composed of 48 items, was analyzed, it was found out that it varied between the values of $r=0.665$ and $\mathrm{r}=0.068$. Item-total correlation coefficient value of five of the items $(13,18,24,28,48)$ were found to be below 0.20 . Among these five items $(13,18,24,28,48)$, only the reliability coefficient of the 28th item was found to be statistically meaningless $(\mathrm{p}=0.253)$ (Table 4$)$. As the reliability coefficient of items $13,18,24$, and 48 was found to be statistically meaningful, regarding these items, no processing was done for removing articles (Table 4). Item 28 was not removed from the scale not to damage the hypothetic structure of the scale[36] and as it could be used in the future studies for analysis.

In order to specify the unchangeability against time (test-retest method) of SCS, the scale was reapplied to 30 individuals two weeks after the first application as regards to parametric statistical testing. [30] As the correlation values obtained after the first and second applications were analyzed, a highly meaningful relationship was found between subscales total scores and total scores of scale, in the positive correlation (Table 5).

\section{Discussion}

In order to analyze the construct validity of SCS, in the scale adaptation studies, instead of Exploratory Factor Analysis (EFA), CFA method was used which was seen as a more appropriate method.[36] Before DFA, KMO analysis was done. It was expected for $\mathrm{KMO}$ value to 


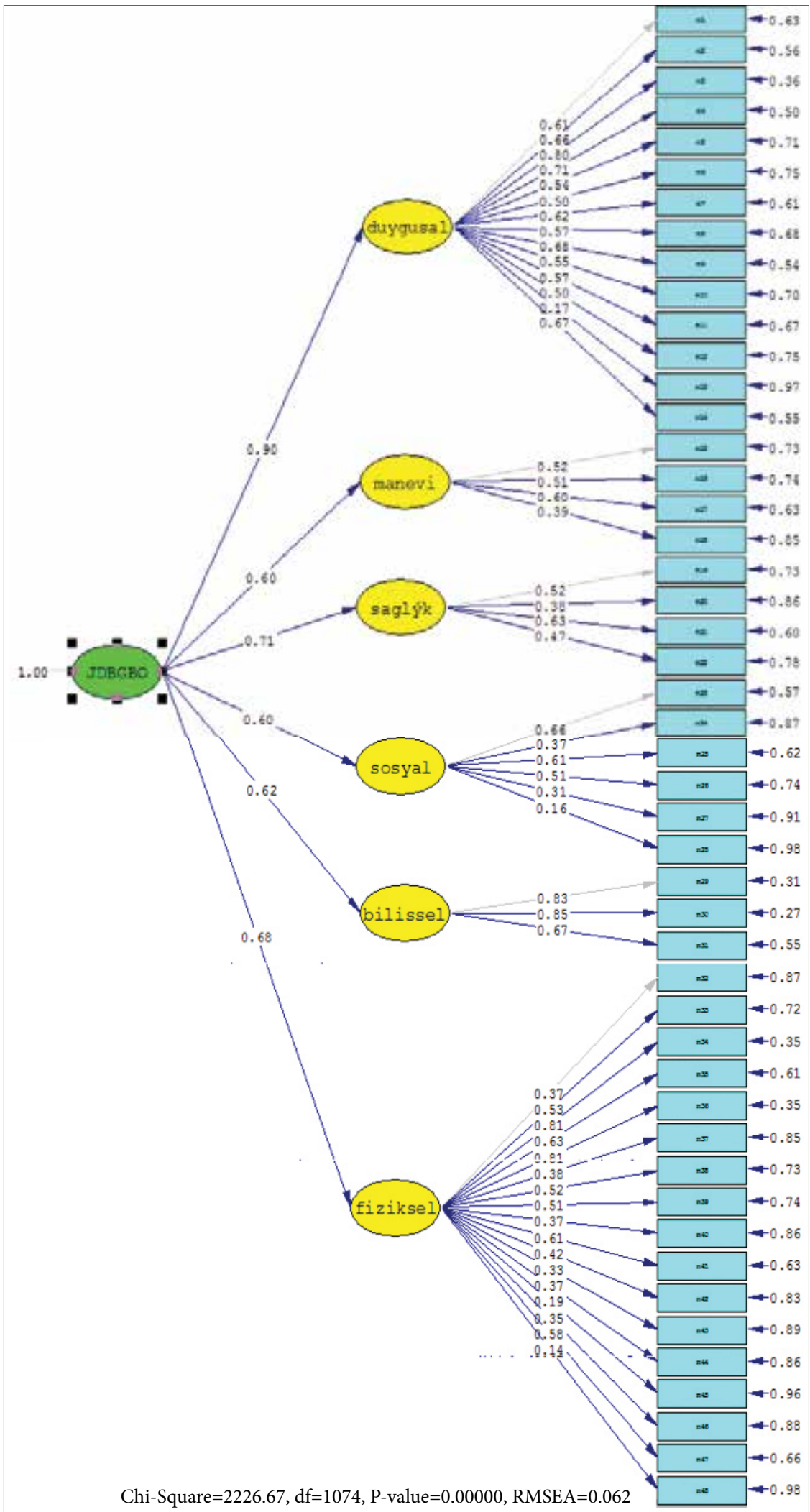

Fig. 1. Defined Model Related 48 items Turkish Form of James Supportive Care Screening. 
Table 2 The relationship between subscales of SCS and subscales of EORTC QLQ C-30 Quality of Life Scale

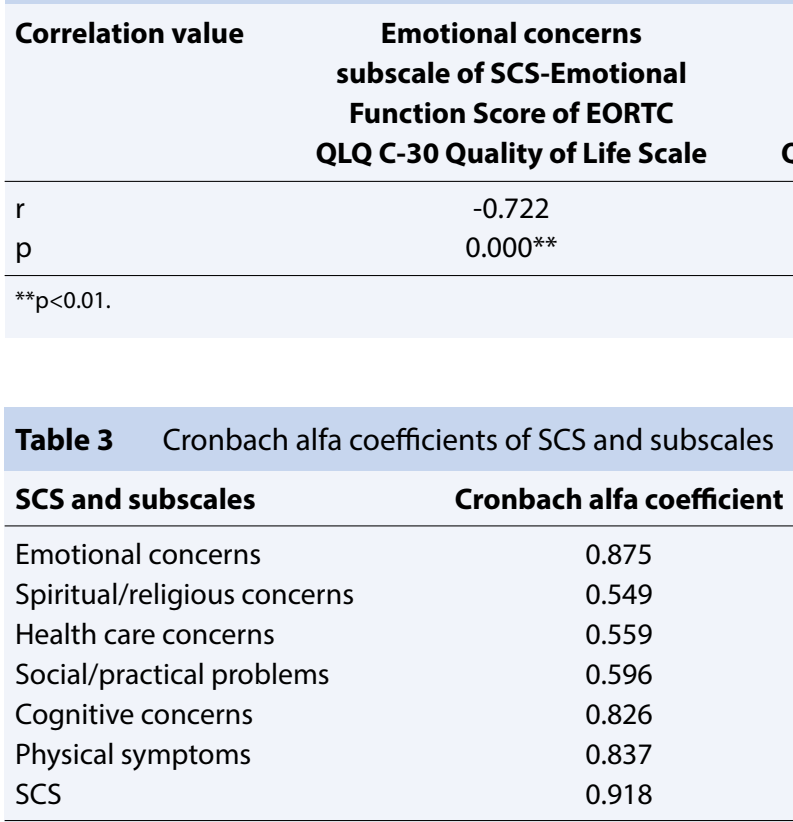

SCS: Supportive Care Screening.

be over 0.60 . As values got closer to 1 , sampling sufficiency improved. KMO values between $0.80-0,89$ are considered as "Good" for sampling sufficiency. KMO value for this research $(\mathrm{KMO}=0.845)$ which was found for this analysis is considered within the range of sampling sufficiency. $P$ value, which was calculated as a result of Bartlett's Test of Sphericity analysis, was found to be $\leq 0.000$. In literature, if $p$ value is below 0.005 , it is seen as the correlation matrix's being appropriate for factor analysis. As p value which was calculated as a result of Bartlett's Test of Sphericity analysis was found to be $\leq 0.000$, it was determined that sampling was in accordance with factor analysis. After Power analysis, sampling was found to be powerful with a rate of $81.3 \%$. This outcome met the requirement specified in literature that sampling should be at least powerful with a rate of $80 \%$.[30] As regards to fit indices determined for Turkish modelling following $\left(\mathrm{X}^{2} / \mathrm{df}=2.073\right.$, RMSEA $=0.62, \quad$ CFI $=0.91, \quad \mathrm{NFI}=0.90, \quad \mathrm{NNFI}=0.91$, $\mathrm{SRMR}=0.07, \mathrm{GFI}=0.90, \mathrm{AGFI}=0.92$ ), as per literature, $\mathrm{X}^{2} / \mathrm{sd}$ was seen as perfect fit index and RMSEA, CFI, NFI, NNFI, GFI, AGFI and SRMR fit indices were seen as good fit indices (Table 1).[37] Furthermore, Turkish modeling illustrated in Figure 1 could measure the structure it was aimed to measure, as valid for the six subscales specified in the original hypothesis (Figure $1)$.

Between the Emotional concerns subscale of SCS and Emotional functional score of EORTC QLQ C-30 Life Quality Scale, a meaningful relationship in the negative correlation was found (Table 2) and between Cognitive Concerns subscale of SCS and Comprehensive function score of Life Quality Scale of EORTC QLQ C-30, again a meaningful relationship was found in the negative correlation (Table 2). A meaningful relationship was found between Physical symptoms subscale of SCS and Symptom scale score of EORTC QLQ C-30 Life Quality Scale in the positive correlation (Table 2). All of the three correlation values found are above 0.70 (Table 2). If the correlation value is above 0.70 , it is interpreted in literature as the validity being high.[30] High score that is obtained from the Emotional functional score of EORTC QLQ C-30 Life Quality Scale shows healthy functional level and high life quality; the high score obtained from Cognitive function score shows high life quality; and the high score obtained from Symptom scale shows that symptoms are experienced heavily and that the life quality is low.[32,33] In SCS, as the score increases, the level of distress also increases.[31] The meaningful relationships found at the research between the subscales of two scales in negative and positive correlation proves the statement in the literature that distress lowers the life quality. $[8,12,38]$

The numbers of female volunteers participating in the research have been more than the number of male participants. As SCS determines the distress being experienced, it focuses on the emotions.[31] It is thought that the reason why number of volunteer males participating in the research is lower than the number of female volunteers is due to the fact that men tend to express their emotions less than women do.[39-41]

As the total score of SCS is analyzed per gender, it is found out that average distress score of women is higher than that of men. In some researches made in literature, it is also specified that the distress level experienced by women is higher than that of men. $[42,43]$ This finding confirms with the literature. 


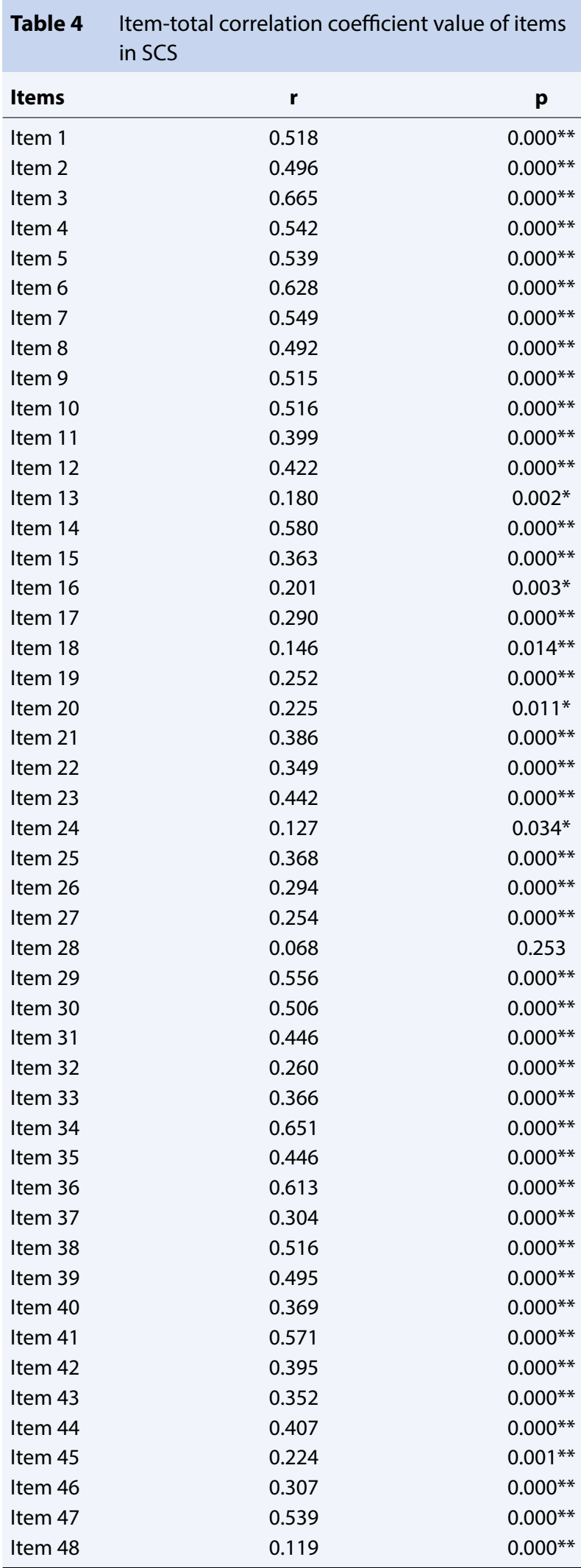

${ }^{*} \mathrm{p}<0.05 ;{ }^{* *} \mathrm{p}<0.01$.
Table 5 Result of test-retest reliability correlation method of SCS and subscales

\begin{tabular}{lcc}
\hline SCS and Subscales & $\mathbf{r}$ & $\mathbf{p}$ \\
Emotional concerns & 0.998 & $0.000^{* *}$ \\
Spiritual/religious concerns & 0.994 & $0.000^{* *}$ \\
Health care concerns & 0.984 & $0.000^{* *}$ \\
Social/practical problems & 0.959 & $0.000^{* *}$ \\
Cognitive concerns & 0.978 & $0.000^{* *}$ \\
Physical symptoms & 0.998 & $0.000^{* *}$ \\
Total score & 0.998 & $0.000^{* *}$ \\
\hline${ }^{* *}<0.01$. & &
\end{tabular}

Cronbach alpha coefficient expected in scale development and adaptation studies in literature is a debatable topic. Cronbach alpha reliability coefficient is only one of the reliability methods. It is not an absolute reliability scale. In some of the researches made in literature, it is stated that Cronbach alpha value should not be lower than 0.50.[44,45] Cronbach alpha values of all subscales of SCS were found to be above 0.50 . Furthermore, in some of the studies Cronbach alpha values in between 0.40 and 0.60 are seen to reflect low reliability.[30,46] Cronbach alpha coefficients of subscales of Spiritual/Religious concerns, Health care concerns, Social/practical problems of SCS were determined to be within low reliability interval (Table 3).[30] Numbers of articles in these three subscales vary between 4 and 6 . As the number of articles decrease, Cronbach alpha coefficient falls down. It is though that this is the reason why Cronbach alpha value of subscales with less number of articles is lower than that of subscales with higher number of articles. [46] Total Cronbach alpha value of SCS was found to be within the high reliability interval of $0.80-1.00$ and it was specified as 0.918 (Table 3). [30]

The item-total correlation coefficient value of five items $(13,18,24,28,48)$ of SCS was determined to be below 0.20 . In literature, it is stated that item-total correlation value should be higher than 0.20.[30] Except for that of article 28 in this five items, the item-total correlation reliability coefficient of all of the items were found to be statistically meaningful (Table 4). As the reliability coefficient of articles with item-total correlation value lower than 0.20 , the item-total correlation reliability coefficient was found to be statistically meaningful in the research conducted by Bilge (2006) as in this research, no processing was not to eliminate any articles.[47] Only the item-total correlation reliability coefficient $(\mathrm{p}=0.253)$ of article 28 which was calculated 
after item-total correlation was found to be statistically meaningless (Table 4). In literature it is specified that omission of an article damages the hypothetic structure of the original scale while adjusting a scale which was developed priory.[36,48] For this reason, no omission was made for article 28 . The total item correlation value of this article will be reviewed again in the future studies to be conducted. In case similar results are obtained, omission of article could be made together with the scale owner by conducting a intercultural study and by repeating validity and reliability studies. $[36,48]$

As the relationship between measurements of SCS for the beginning study and for the one applied two weeks later was analyzed, the correlation value specifying the relation between all subscales and scale total score was found to be in the perfect reliability interval of 0.95 and 1.00 (Table 5).[30] With the correlation values found, the unchangeability of scale against time was proven.

\section{Conclusion}

The SCS is composed of six subscales and 48 questions in the total. After the adjusted study was conducted, it was proven that the scale is a valid and reliable measurement tool for this sampling group of Turkish community. It is recommended for the scale to be implemented for wider sampling groups in the future studies and for the item-total correlation correlation value of item 28 to be reviewed again. Additionally, on the original form of the scale, there are 8 pieces of clinical questions which were not included in the scale scoring. In the studies where the scale will be applied, these questions and the clinical questions could also be used to avoid any problems to be missed.

\section{Disclosure Statement}

The authors declare no conflicts of interest.

\section{References}

1. Türkiye Cumhuriyeti Sağlık Bakanlığı. Kanser Konusunda Genel Bilgiler. Ankara: Türkiye Cumhuriyeti Sağlık Bakanlığı Yayınları, 2001.

2. Türkiye Cumhuriyeti Sağlık Bakanlığı. Türkiye'de Kanser İstatistikleri. Ankara: Türkiye Cumhuriyeti Sağlık Bakanlığı Yayınları, 2014.

3. Dedeli Ö, Karadeniz G. An integrated psychosocialspiritual model for cancer pain management. Agri 2009;21(1):45-53.
4. Rainbird K, Perkins J, Sanson-Fisher R, Rolfe I, Anseline $\mathrm{P}$. The needs of patients with advanced, incurable cancer. Br J Cancer 2009;101(5):759-64. Crossree

5. Altınova $\mathrm{HH}$, Duyan V. Oncological social work. TJFMPC 2013;7(3):40-5. Crossret

6. Yıldırım NK, Kaçmaz N, Özkan M. Unmet care needs in advanced stage cancer patients. Psikiyatri Hemşireliği Dergisi 2013;4(3):153-8.

7. Maguire R, Papadopoulou C, Kotronoulas G, Simpson MF, McPhelim J, Irvine L. A systematic review of supportive care needs of people living with lung cancer. Eur J Oncol Nurs 2013;17(4):449-64. Crossree

8. National Comprehensive Cancer Network (NCCN). Washington: Clinical Practice Guidelines in Oncology, 2014 [Available at: 15.02.2016]. https://www.nccn. org/about/contact.aspx.

9. Zainal N, Hui K, Hang T, Bustam A. Prevalence of distress in cancer patients undergoing chemotherapy. Asia Pac J Clin Oncol 2007;3:219-23. Crossre

10. Liao MN, Chen SC, Chen SC, Lin YC, Chen MF, Wang $\mathrm{CH}$, et al. Change and predictors of symptom distress in breast cancer patients following the first 4 months after diagnosis. J Formos Med Assoc 2015;114(3):246-53. Crossree

11. Bergerot CD, Tróccoli BT, Philip EJ, Buso MM. Percentile curve of distress scores as a clinical aid for the evaluation and management of cancer patient's distress. Psychooncology 2014;23(9):1068-72. Crossreet

12. Thalen- Lindström AM, Glimelius BG, Johansson BB. Identification of distress in oncology patients: a comparison of the hospital anxiety and depression scale and a thorough clinical assessment. Cancer Nursing 2016;39(2):31-9. Crossret

13. Sostaric M, Sprah L. Psychological distress and intervention in cancer patients treated with radiotherapy. Radiol Oncol 2004;38(3):193-203.

14. Gültekin Z, Pınar G, Pınar T, Kızıltan G, Doğan N, Algier L, et al. Health-Related Quality of Life and Health Care Services Expectations of The Patients with Lung Cancer. UHOD 2008;18(2):99-106.

15. Tsai JS, Wu CH, Chiu TY, Chen CY. Significance of symptom clustering in palliative care of advanced cancer patients. J Pain Symptom Manage 2010;39(4):65562. Crossret

16. Robinson JW, Donnelly BJ, Saliken JC, Weber BA, Ernst S, Rewcastle JC. Quality of life and sexuality of men with prostate cancer 3 years after cryosurgery. Urology 2002;60(2 Suppl 1):12-8. Crossrel

17. Errihani E, Elghissassi I, Mellas N, Belbaraka R, Messmaudi M, Kaikani W. Impact of cancer on sexuality: How is the Moroccon patient affected? Sexologies 2010;19(2):92-8. Crossret 
18. Aranda S, Schofield P, Weih L, Yates P, Milne D, Faulkner R, et al. Mapping the quality of life and unmet needs of urban women with metastatic breast cancer. Eur J Cancer Care (Engl) 2005;14(3):211-22.

19. Uchida M, Akechi T, Okuyama T, Sagawa R, Nakaguchi T, Endo C, et al. Patients' supportive care needs and psychological distress in advanced breast cancer patients in Japan. Jpn J Clin Oncol 2011;41(4):53036. Crossre

20. Akechi T, Okuyama T, Endo C, Sagawa R, Uchida M, Nakaguchi T, et al. Patient's perceived need and psychological distress and/or quality of life in ambulatory breast cancer patients in Japan. Psychooncology 2011;20(5):497-505. Crossre

21. Daştan NB, Buzlu S. The Effects Of Spirituality In Breast Cancer Patients And Spiritual Care. Maltepe Üniversitesi Hemşirelik Bilim ve Sanatı Dergisi 2010;3(1):73-8.

22. Gualdani S, Pegoli M. Spirituality in health care: The role of needs in critical care. Trends in Anaesthesia and Critical Care 2014;4(6):175-7. Crossre

23. Kruijver IP, Garssen B, Visser AP, Kuiper AJ. Signalising psychosocial problems in cancer care the structural use of a short psychosocial checklist during medical or nursing visits. Patient Educ Couns 2006;62(2):163-77. Crossre

24. Bramsen I, van der Linden MH, Eskens FJ, Bijvank EM, van Groeningen CJ, Kaufman HJ, et al. Evaluation of a face-to-face psychosocial screening intervention for cancer patients: acceptance and effects on quality of life. Patient Educ Couns 2008;70(1):61-8.

25. Bag B. Psycho-Oncology, Psychosocial Problems and Measurement Methods. Psikiyatride Güncel Yaklaşımlar 2012;4(4):449-64. Crossre

26. Özçelik H, Fadıloğlu Ç, Uyar M, Karabulut B. Kanser hastaları ve aileleri için palyatif bakım. İzmir: Üniversite Opset, 2010.

27. Harrison JD, Young JM, Price MA, Butow PN, Solomon MJ. What are the unmet supportive care needs of people with cancer? A systematic review. Support Care Cancer 2009;17(8):1117-28. Crossre

28. Ercan İ, Kan İ. Reliability and Validity in The Scales. Uludağ Üniv Tip Fak Derg 2004;30(3):211-6.

29. Deniz KZ. The Adaptation of Psychological Scales. Ankara Üniversitesi Eğitim Bilimleri Fakültesi Dergisi 2007;40(1):1-16.

30.Alpar R. Spor, Sağlık ve Eğitim Bilimlerinden Örneklerle Uygulamalı İstatistik ve Geçerlik - Güvenirlik, 1. Basım. Ankara: Detay Yayıncılık; 2011.

31. Wells-Di Gregorio S, Porensky EK, Minotti M, Brown S, Snapp J, Taylor RM, et al. The James Supportive Care Screening: integrating science and practice to meet the NCCN guidelines for distress management at a Comprehensive Cancer Center. Psychooncology 2013;22(9):2001-8. Crossret

32. Guzelant A, Goksel T, Ozkok S, Tasbakan S, Aysan T, Bottomley A. The European Organization for Research and Treatment of Cancer QLQ-C30: an examination into the cultural validity and reliability of the Turkish version of the EORTC QLQ-C30. Eur J Cancer Care (Engl) 2004;13(2):135-44. Crossre

33. Fayers PM, Aaronson NK, Bjordal K, Groenvold M, Curran D, Bottomley A. On behalf of the EORTC Quality of Life Group. The EORTC QLQ-C30 Scoring Manual. 3rd ed. Brussels: EORTC; 2001.

34. Yurdugül, H. Ölçek geliştirme çalışmalarında kapsam geçerliği için kapsam geçerlik indekslerinin kullanılması. XIV. Ulusal Eğitim Bilimleri Kongresi (28-30 Eylül 2005, Denizli).

35. Erkorkmaz Ü, Etikan İ, Demir O, Özdamar K, Sanisoğlu SY. Confirmatory Factor Analysis and Fit Indices: Review. Turkiye Klinikleri J Med Sci 2013;33(1):210-23. Crossret

36. Çüm S, Koç N. Türkiye'de psikoloji ve eğitim bilimleri dergilerinde yayımlanan ölçek geliştirme ve uyarlama çalışmalarının incelenmesi. Eğitim Bilimleri ve Uygulama 2013;12(24):115-35.

37. Schumacker RE, Lomax RG. A Beginner's Guide to Structural Equation Modeling. 2nd ed. New Jersey: Lawrence Erlbaum Associates Publishers; 1996.

38. Miller MF, Mullins CD, Onukwugha E, Golant M, Buzaglo JS. Discriminatory power of a 25 -item distress screening tool: a cross-sectional survey of 251 cancer survivors. Qual Life Res 2014;23(10):2855-63. Crossret

39. Akan ŞT, Barışkın E. Reliability and Validity Indicators of Berkeley Expressivity Questionnaire in the Context of Culture and Gender. Türk Psikiyatri Dergisi 2015;26:1-8.

40. Parkins R. Gender and emotional expressiveness: An analysis of prosodic features in emotional expression. Pragmatics and Intercultural Communication 2012;5(1):46-54.

41. Boratov HB, Sunar D, Ataca B. Emotional Display Rules and Their Contextual Determinants: An Investigation with University Students in Turkey. TPD 2011;26(68):90-101.

42. Nurullah AS. Gender differences in distress: the mediating influence of life stressors and psychological resources. Asian Social Science 2010;6(5):27-35.

43. Herschbach P, Book K, Brandl T, Keller M, Lindena G, Neuwöhner K, et al. Psychological distress in cancer patients assessed with an expert rating scale. Br J Cancer 2008;99(1):37-43. Crossre

44. University of Virginia Library Research Data Services. 
Charlottesville: Using-And-Interpreting-CronbachAlpha, 2016 [Available at: 02.05.2016]. http://data. library.virginia.edu.

45. Santos JRA. Cronbach's Alpha: A tool for assessing the reliability of scales. J Extension 1999;37(2):1-4.

46. Tavakol M, Dennick R. Making sense of cronbach's alpha. International Journal of Medical Education
2011;2:53-5. Crossre

47. Bilge A. Ruhsal Hastalığa Yönelik İnançlar Ölçeği Geçelilik ve Güvenilirlik Çalışması. Yayımlanmış Uzmanlık Tezi. İzmir: Ege Üniversitesi Atatürk Sağlık Yüksekokulu, 2007.

48. Öztürk NB, Eroğlu MG, Kelecioğlu H. Eğitim alanında yapılan ölçek uyarlama makalelerinin incelenmesi. Eğitim ve Bilim 2015;40(178):123-37. 